OPEN ACCESS

Edited by:

Tien Ming Lee,

Sun Yat-sen University, China

Reviewed by:

Laura Thomas-Walters, University of Stirling, United Kingdom David L. Roberts,

University of Kent, United Kingdom

*Correspondence: Jared D. Margulies jdmargulies@ua.edu

Specialty section: This article was submitted to Conservation and Restoration

Ecology,

a section of the journa

Frontiers in Ecology and Evolution

Received: 10 September 2020 Accepted: 29 September 2020

Published: 23 October 2020

Citation:

Margulies JD (2020) Korean 'Housewives' and 'Hipsters' Are Not

Driving a New Illicit Plant Trade: Complicating Consumer Motivations Behind an Emergent Wildlife Trade in Dudleya farinosa.

Front. Ecol. Evol. 8:604921. doi: 10.3389/fevo.2020.604921

\section{Korean 'Housewives' and 'Hipsters' Are Not Driving a New Illicit Plant Trade: Complicating Consumer Motivations Behind an Emergent Wildlife Trade in Dudleya farinosa}

\author{
Jared D. Margulies* \\ Department of Geography, University of Alabama, Tuscaloosa, AL, United States
}

Illegal trade in wild plants receives less scientific and policy attention than illegal trade in wild animals and animal-derived products. One exception to this generalizable trend is the recent emergence of an illegal trade in the California succulent species Dudleya farinosa. US officials and mainstream media reporting on these incidents suggest the final destination of these plants is succulent consumer markets in South Korea and other East Asian countries. It is believed that this illegal trade emerged in response to sudden and widespread consumer demand for succulents due to: (1) the increasing popularity of succulent plants in mainstream South Korean and East Asian cultures writ large; and (2) the preferential valuing of 'wild' versus cultivated plants by succulent consumers. Based on findings from content analysis of media reports and in-depth qualitative interviews in California and South Korea, I argue instead for a more nuanced perspective of the drivers of this emergent trade, with the primary motivational desire for these plants coming from a selective and highly skilled community of succulent enthusiasts, rather than mainstream plant consumer groups. In presenting these findings I demonstrate the importance of in-depth, critical qualitative research for exploring the emergence of particular trades in wildlife in order to inform more sustainable and legal trades. I clarify the primary drivers of this new trade in Dudleya farinosa as an illegal but logical response to the economics and temporalities of plant trade. I offer suggestions on how these findings can inform more sustainable solutions to the illicit extraction of wild plants in meeting consumer demand.

Keywords: conservation social science, plant trade, illegal wildlife trade (IWT), succulents, poaching, California, South Korea

\section{INTRODUCTION}

There is proportionally limited scientific research on illegal trades in plants compared to animals (Wyatt, 2013; Lavorgna et al., 2018; Margulies et al., 2019a). Within the plant kingdom, research on known existing illicit trades beyond timber is patchy, and limited to only few taxa, such as orchids (Phelps and Webb, 2015; Hinsley et al., 2016, 2017; de Boer et al., 2017). Despite the high volume of international illegal trade in many cactus and succulent plant species, there remains very little 
published scientific research on their illegal trade (but see Sajeva et al., 2007; Goettsch et al., 2015; Lavorgna and Sajeva, 2020). In general, international illegal trades in succulent plants, such as cacti and cycads, among other succulents, exist when a plant's trade is restricted or regulated under the Convention on International Trade in Endangered Wild Fauna and Flora (CITES), or when they are acquired in an illegal manner (such as cases involving trespassing and illegal extraction). The primary value of illegally traded succulents is in their aesthetic qualities valued by plant collectors (Sajeva et al., 2007; Goettsch et al., 2015). There is very little empirical data on how succulent trades function, or what motivates consumer choices in collecting or purchasing plants traded illegally, including the scale, scope, and foundational drivers behind these trades (Hinsley et al., 2016; Lavorgna et al., 2018; Wyatt et al., 2020).

It is perhaps unsurprising that illegal plant trade rarely features prominently in high-level fora on illegal wildlife trade (IWT) or in IWT funding programs, given the longstanding taxonomic biases that persist within biodiversity conservation efforts toward charismatic megafauna in efforts to combat wildlife trafficking (Fukushima et al., 2020; Massé and Margulies, 2020; Massé et al., 2020). Another consequence of this general inattention to plants is that despite the long-standing awareness within conservation circles of global illegal succulent trades, these trades have historically received scant attention from media and press outlets. This is beginning to change, however, and a variety of recent incidents of succulent poaching have received widespread media attention. The unusual limelight cast on these incidents is likely a result of both the increasing global popularity of succulents amongst mainstream consumers, alongside the headline-grabbing potential of unusual stories about 'succulent smugglers', 'plant poachers,' or 'cactus rustlers.' One example of illegal succulent trade receiving widespread international attention involves the theft of the succulent species Dudleya farinosa from within its habitat range in California, United States. D. farinosa also goes by the common names of powdery liveforever, bluff lettuce, sea lettuce, or siemprevivas (Figure 1). Based on research conducted in 2018-2019, in this article I offer a critique of many of the explanations and justifications offered in media reporting on the emergent trade in D. farinosa. In particular, I draw the title of this article from the frequent use of "housewives" and "hipsters" as general coded categories of mass-consumer markets many articles suggested were responsible for the rapid rise in this illegal trade.

Legal, regulated mechanisms exist for the purchase, sale, and international trade of cultivated $D$. farinosa. No species of the Dudleya genus is currently listed on the appendices of CITES, the primary international agreement regulating trade in wildlife. Two species of Dudleya-D. stolonifera and D. traskiae-were previously listed on CITES appendices (first Appendix I, then downgraded to Appendix II) due to their limited habitat range, threatened status, and previous concerns about illegal trade at the time of their listing in 1983 . However, these species were later delisted from CITES during the Sixteenth meeting of the Conference of the Parties in 2013 as it was believed they did not face any threat from international trade (Convention on International Trade in Endangered Species of Wild Fauna and
Flora, 2013). Although IUCN Red List assessments have not been carried out for any member of the Dudleya genus, a number of Dudleya species are listed on California State and/or the US Federal list of endangered species, but $D$. farinosa is not (California Natural Diversity Database [CNDDB], 2020). Because it is not a threatened or endangered plant, D. farinosa is also not protected by the U.S. Lacey Act which prohibits the import, export, transport, and sale via interstate or international commerce of CITES-listed plants or those protected by State endangered species laws. Unlike some threatened or endangered Dudleya species, $D$. farinosa has a wide distribution range. $D$. farinosa is a coastal dwelling species inhabiting a narrow ecotone along steep coastal bluffs ranging from southern Oregon in the North to Santa Barbara, CA in the South (McCabe, 2012). It is therefore important to clarify that because $D$. farinosa is not a CITES-listed species nor listed as threatened or endangered by state or federal authorities, what makes its trade illegal refers specifically to the ways in which it was either (a) illegally acquired (e.g., taken without permission from private or public lands), and/or (b) traded in a manner that violated US or international shipping regulations (e.g., failing to be shipped with necessary phytosanitary permits, false filing with the postal service, etc.).

The available legal channels for international trade in $D$. farinosa make the existence of an illegal international trade all the more surprising, as in theory there are legal markets by which consumers desiring $D$. farinosa can obtain them. With this in mind, inductive qualitative research was conducted in order to pursue the following core research questions: (1) why did an illegal trade in D. farinosa emerge? (2) Who were the primary consumers for poached D. farinosa? (3) What motivated consumer desire for these plants? The motivations behind trade in wildlife products are typically complex and multifaceted, and can be difficult to fully characterize through quantitative methods alone (e.g., Zhu, 2020). Rarely do simple narratives effectively capture the complex social motivations mediating choices actors make in engaging in criminal behaviors that impact wildlife, or the preferences of consumers for legal or illegal wildlife products (Hübschle, 2017; Wong, 2019; Hinsley and 't SasRolfes, 2020; Zhu and Zhu, 2020). Based on in-depth qualitative research in both California and South Korea on the recent rise of an illegal $D$. farinosa trade, this article complicates simplistic narratives circulating in both mainstream media outlets as well as amongst law enforcement organizations and plant conservation communities about the consumer motivations driving $D$. farinosa poaching from California. Further, in presenting evidence for the motivations behind this trade, this article holds a mirror to commonplace narratives of wildlife consumption patterns in East Asia rooted in blunt stereotypes of Asian consumer habits and global patterns of wildlife trade that are persistent within both the conservation and wildlife trade sectors (Margulies et al., 2019b). While there are a variety of valuable and important methodologies available for researching drivers of IWT and consumer preferences for particular wildlife products, this article demonstrates the critical value of qualitative research early on in the study of IWTs. Qualitative research can reveal important context and nuance related to consumer motivational behavior, which in turn can help inform the development of legal, alternative, and more sustainable trades. 


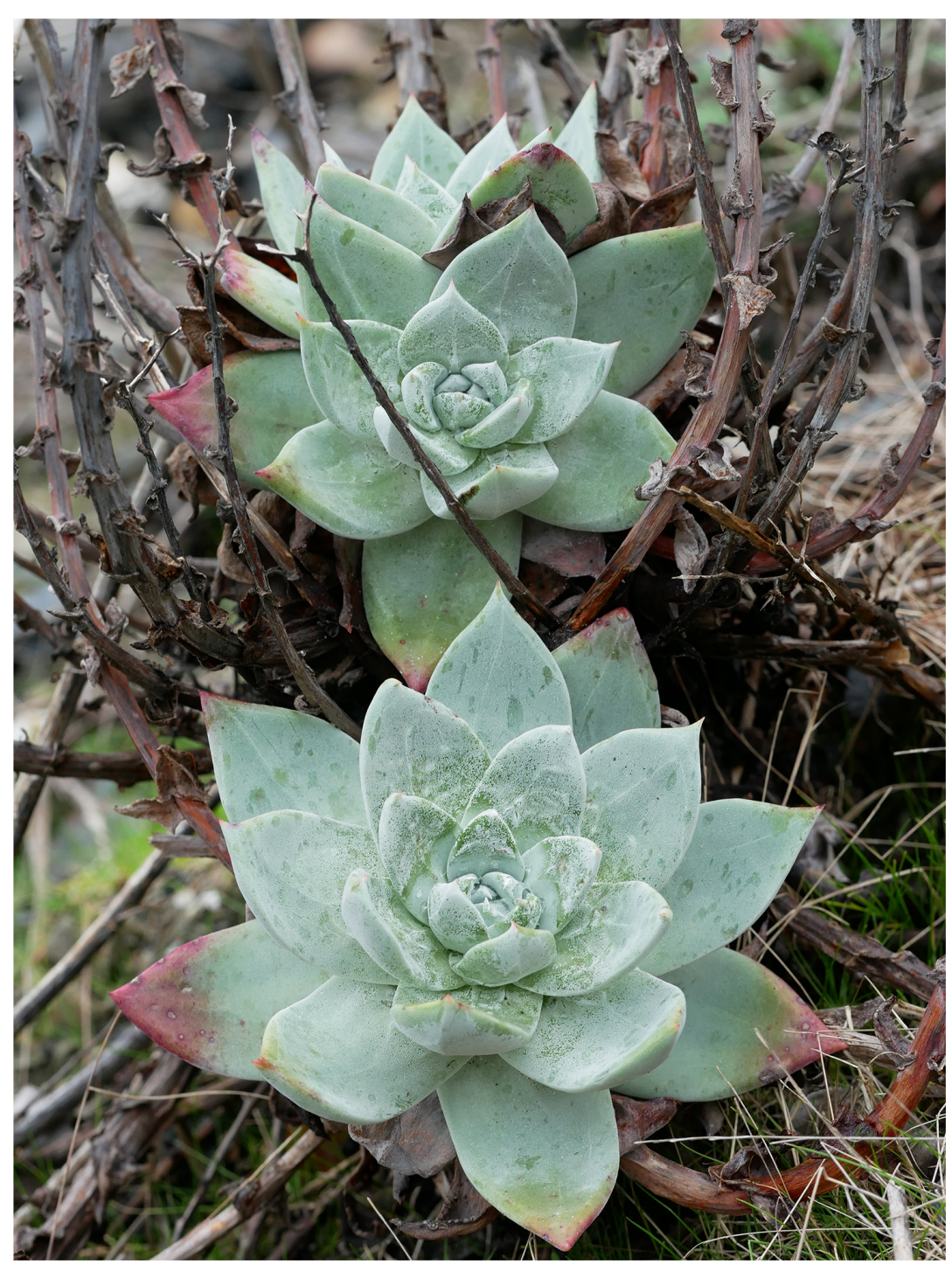

FIGURE 1 | Dudleya farinosa, near Eureka, CA, United States. Photograph by the author.

\section{MATERIALS AND METHODS}

I employed semi-structured qualitative interviews as well as qualitative media content analysis and document collection (such as court cases, depositions, etc.) adopting a methodology that Ballvé (2020) recently described as 'investigative ethnography.' Investigative ethnography represents a blended research approach combining the interest in fact-finding and use of public records related to incidents of wrongdoing familiar to investigative journalism, with the contextual and interpretivist work of ethnography as thick description (Ballvé, 2020). In this sense I was both interested in some of the basic questions a rigorous journalist might pursue in uncovering the 'true' nature of this illicit trade, while at the same time I approached these questions through the inductive lens of ethnographic inquiry. An ethnographic perspective demands a critical stance toward ideas of the neutral positionality as a researcher, as a researcher, and an equally critical stance towards the idea of an objective or singular 'truth' about the drivers and mechanisms underlying this emergent illicit trade (Ballvé, 2020).

While analyzing interviews, court records, news reports, and documents represents a form of research triangulation via comparison useful for understanding what is known about the supply side dimensions of this illicit trade, I employed qualitative interviews in South Korea to generate a fuller appreciation of the nuances and complexities around the drivers of demand for D. farinosa and what motivates succulent enthusiasts to acquire them. This approach relied on developing theoretical saturation related to themes of consumer motivation employing the use of constant comparison as an iterative technique to ensure that data was analyzed and compared throughout the research process in order to inform further research and theory generation (Glaser, 
1965; Maxwell, 2012; Fram, 2013). Inductive theoretical codes emergent from this process were applied to interview transcripts and managed within the qualitative data analysis software NVivo (QSR International). This inductive research approach was more appropriate to this study of $D$. farinosa trade than other research methods such as larger consumer-oriented surveys for several reasons (e.g., Doughty et al., 2019). First, there was no baseline data from which to support a survey tool or other statistically robust form of measurement. Second, the market for $D$. farinosa is highly dispersed and selective, as well as international (not just confined to South Korea), making survey implementation with targeted consumers extremely difficult due to access and privacy concerns. Third, while there is an uneven appreciation of the illicit status of wild-harvested $D$. farinosa in Korea, it made the subject a possibly sensitive topic that could not be easily broached; it required longer-form interviews with research subjects before the subject of illicit acquisition could be discussed, if at all (Dang Vu et al., 2020). Fourth, the goal of this research was to develop a generalizable understanding of a suite of motivations and desires within succulent consumer groups, rather than testing a particular variable against a set of dependent variables.

I conducted $(N=15)$ in-depth semi-structured interviews ranging from $45 \mathrm{~min}$ to $2.5 \mathrm{~h}$ in California with relevant commercial succulent growers, California Department of Fish and Wildlife staff, and conservationists with known expertise or particular insight into the $D$. farinosa trade using a snowball sampling protocol. In Korea I similarly conducted indepth semi-structured interviews with key commercial succulent growers and succulent enthusiasts and experts $(N=12)$ as well two small group interviews with Korean government agency officials with expertise or regulatory purview over Korean wildlife trade regulations (1) and the Korean succulent industry (1). Because I was focusing on key expert/specialist perspectives and insights, this snowball-sampling protocol was most appropriate as it enabled experts to identify other important experts and specialists that they felt would be informative for this research. In both South Korea and in the United States, I suspended recruitment for additional interviewees once experts continued to identify the same individuals I had already either contacted or interviewed. In South Korea, initial contacts were identified by conducting online research on specialist and large scale commercial greenhouses focusing on succulent plants in Korea, with particular emphasis on specialist dealers who specifically advertised possessing and selling $D$. farinosa. During both sets of interviews a basic interview guide comprised of 20 questions was utilized, broken down by questions on (1) the general popularity and growth of the Korean/US succulent industry and consumer market; (2) questions related to plant conservation, trade and law enforcement/regulatory issues; and (3) more specific questions about the Dudleya genus and consumer demand. In South Korea I also visited numerous commercial succulent nurseries and wholesalers in order to assess the presence or absence of $D$. farinosa as a means of triangulating interview responses about their availability, as well as to take detailed notes on which species of succulents appeared most popular with Korean succulent consumers based on stocking patterns. Further, this research was informed by 2 years of in-depth qualitative research on the global illicit succulent trade writ large, including more than 85 indepth interviews with succulent consumers and enthusiasts, law enforcement officials, succulent dealers, and succulent smugglers.

I compiled a set of online English language $(N=15)$ as well as Korean language news articles $(N=14)$ reporting on the emergence of the Dudleya trade using a simple Boolean search strategy run through the Google search engine ["dudleya farinosa" AND ("theft" OR “poaching” OR "illegal”)]. I excluded informal forum threads (via sites like reddit.com) and personal blog posts from my analysis. While there were many more news articles available than those I compiled, many smaller and regional newspapers and online news sites recycled the same quotes and material from previously published articles. It was not my aim to conduct a systematic media content analysis, but instead focus on key themes emergent in the most widely circulated and read articles published by major news outlets on the subject. I applied Thomas-Walters et al.'s (2020a) framework for understanding the motivations behind the use of wildlife products as a coding system for media content analysis (Altheide and Schneider, 2012). Articles were coded with a total of 5 primary codes and 15 secondary codes (Figure 2). I suspended content analysis once I had analyzed enough articles that no new major motivational behavior narratives emerged (point of theoretical saturation). The same codebook was applied post hoc to transcribed interviews conducted with Korean succulent dealers and consumers as a secondary round of coding.

\section{RESULTS AND DISCUSSION}

\section{A New Illegal Trade}

Beginning in late 2017, California's Department of Fish and Wildlife (CDFW) became aware of a growing problem of $D$. farinosa poaching by foreign nationals in multiple, unrelated incidents. The first reported incident in December 2017 was presumed by CDFW to be an isolated matter, and CDFW was alerted to the issue by a citizen who was suspicious of a man attempting to ship a large number of packages from a small post office in Mendocino, California. The citizen observed dirt falling out of the packages and was concerned it was an issue of abalone poaching, a problem common to the area, and therefore contacted the CalTip hotline, a citizen reporting line to alert them of her suspicions (CDFW Interview, January 18, 2019). A month later, the same officer who followed up on this incident observed behavior he suspected indicated abalone poaching near the town of Point Arena, California. Instead, he discovered a man harvesting D. farinosa. In March of 2018, the same officer apprehended two Korean foreign nationals stealing 850 D. farinosa from private property. The men also had in their possession the names of a variety of international succulent commercial operations.

This wasn't their first rodeo. These guys were global plant poachers. If you looked at their paperwork, it was all vendors, and vendors' purchase lists" (CDFW interview, January 18, 2019).

At this point, CDFW realized this was no longer a matter of just one or two isolated incidents, but small groups of people 


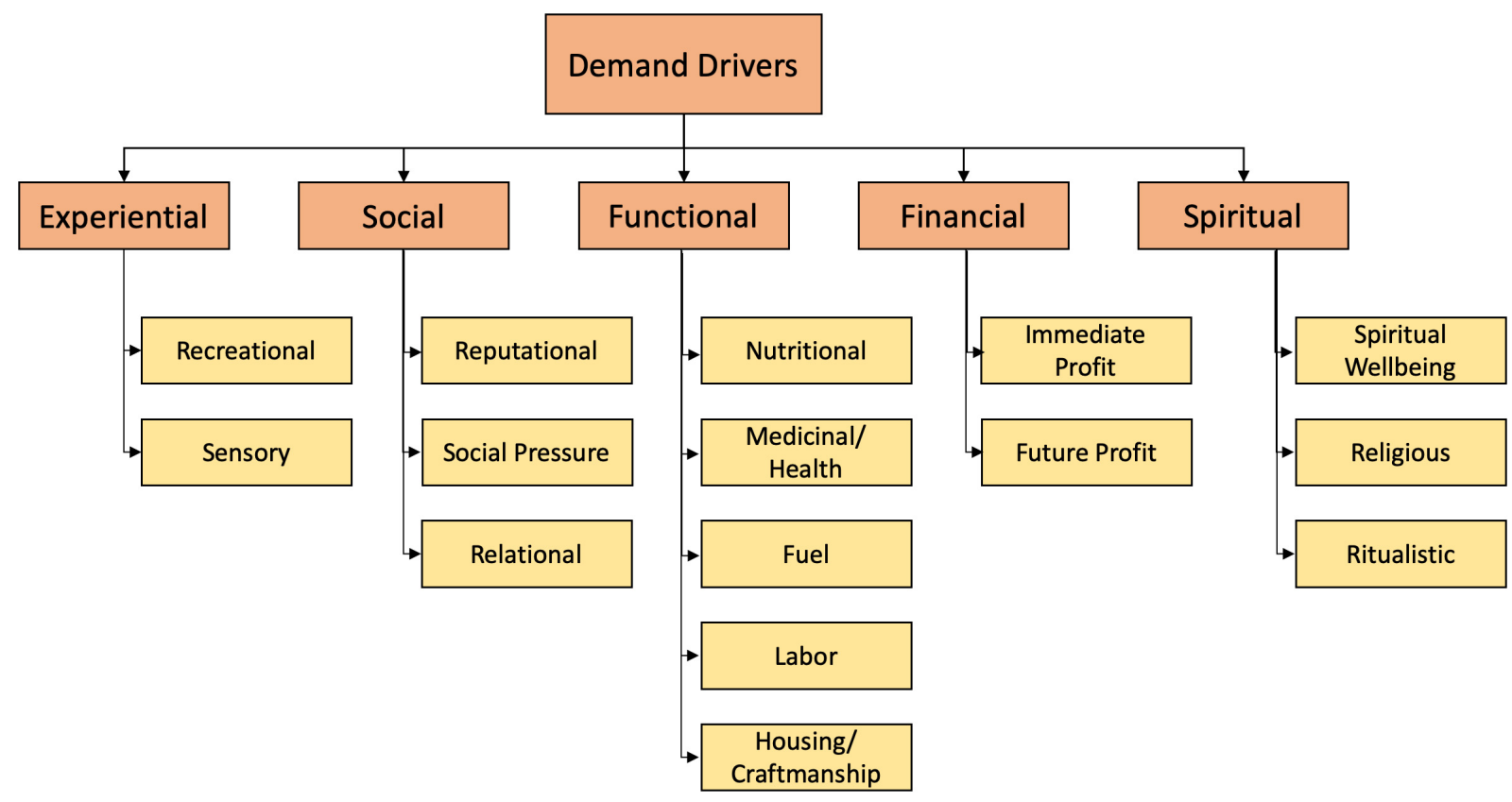

FIGURE 2 | Framework for the motivations behind the use of wildlife products adapted from Thomas-Walters et al. (2020a).

taking increasingly large volumes of plants (CDFW Interview, January 16, 2019).

Between 2017-2108, there were at least six known incidents of attempts by foreign nationals to harvest and/or ship wild grown $D$. farinosa from California. The size and scope of these incidents varied, ranging from single actors being caught with approximately 50 plants, to repeated incidents of several actors arrested, working in coordination to ship thousands of individual wild-harvested plants in shipments believed by CDFW to be worth in excess of 1,000,000 USD (CDFW Interview, January 16, 2019; court documents). However, expert interviewees and court documents reveal that other incidents of illegal Dudleya poaching and international shipments had likely occurred during at least the past several years, though perhaps smaller in scale or magnitude (Dudleya expert interview, January 22, 2019). Further, the problem of Dudleya poaching is not exclusively restricted to California or the farinosa species, as a major incident in May in Baja California, Mexico demonstrated, involving the interception of several thousand poached Dudleya pachyphytum from Isla de Cedros off the Baja coast (Investigaciones Zeta, 2018).

\section{Motivations for Acquiring Dudleya farinosa Expressed in Media Reports}

While media articles offered a variety of explanations for the sudden emergence of illicit $D$. farinosa trade, to date there has been no academic research on the subject, an important step toward developing meaningful responses and sustainable solutions grounded in empirical data. Table 1 summarizes (a) consumer motivations for $D$. farinosa described in online media articles; and (b) consumer motivations described by Korean experts in the succulent consumer market and collecting community. I conducted content analysis of a total of 18 news articles in both English and Korean (10 English, 9 Korean), the latter facilitated by working with research assistants fluent in Korean. Due to the limited number of relevant articles (many articles, particularly in Korean, were repetitive of previously published articles), I do not quantify the frequency of each code's occurrence; instead Table 1 describes a range of the most frequently referenced motivations for consumer desire in order to fully characterize the suite of perceived possibilities for D. farinosa consumer interest. This framework is useful as a form of consumer demand categorization; it does not, in contrast, focus on supply side dimensions, such as the profit motive for those illegally acquiring $D$. farinosa and their subsequent sale to consumers or wholesalers. Here, the focus is on why a consumer demand exists in the first place for $D$. farinosa driving their illicit acquisition. I provide examples of these understandings of motivation categorized in Table $\mathbf{1}$ by code category in Table 2 .

Most news articles gave multiple reasons for consumer motivational use of D. farinosa. For instance, multiple Korean news sites either closely reproduced and/or repeated the following statement:

Like cactus, Dudleya is a plant that contains water in its leaves and stems to live in a dry climate. It's also in the limelight as an investment tool in South Korea for its air purifying effect and home decoration use.

두들레야는 선인장처럼 건조한 기후에 살기 위해 잎과 줄기에 수분을 함유한 식물로 공기정화와 인테리어 효과가 있어 국내에서 재테크 수단으로도 각광 받고 있습니다.

In this frequently occurring statement, the coded motivational categories are: Experiential-Sensory (home-decoration); 
TABLE 1 | Motivations for acquiring Dudleya farinosa by consumers as described in (a) new media reporting on this trade and (b) interviewed Korean succulent dealers and collectors.

\begin{tabular}{|c|c|c|c|c|c|}
\hline \multirow[b]{2}{*}{ Narrative Group } & \multicolumn{5}{|c|}{ Motivations } \\
\hline & Experiential & Social & Functional & Financial & Spiritual \\
\hline News Media Outlets & Recreational and Sensory & Reputational & Medicinal & Future Profit & Spiritual well being \\
\hline Korean Succulent Dealers and Collectors & Recreational and Sensory & Relational & - & - & - \\
\hline
\end{tabular}

Motivational framework adopted from Thomas-Walters et al. (2020a).

TABLE 2 | Examples of excerpts of news articles coded by sub-categories from the applied framework of Thomas-Walters et al. (2020a).

\begin{tabular}{|c|c|c|}
\hline & Category description & Excerpts from news media reporting \\
\hline $\begin{array}{l}\text { Experiential- } \\
\text { Recreational }\end{array}$ & $\begin{array}{l}\text { Motivated by the desire for leisure or } \\
\text { pursuit of a pastime or hobby. }\end{array}$ & $\begin{array}{l}\text { "In the Asian country [South Korea], tending succulents had become a favorite pastime across } \\
\text { generations, popular with everyone from harassed housewives to Generation-Z hipsters. And with all } \\
\text { things Korean - from fashion and music to food and soap operas - grabbing the popular imagination in } \\
\text { China, the world's most populous nation had caught a massive dose of dudleya fever." (Lanyon, 2018) }\end{array}$ \\
\hline $\begin{array}{l}\text { Experiential- } \\
\text { Sensory }\end{array}$ & $\begin{array}{l}\text { Motivated by the desire to please the } \\
\text { senses, including aesthetic, olfactory, } \\
\text { and tactile. }\end{array}$ & $\begin{array}{l}\text { "Native Dudleya plants from coastal habitats in Northern California are particularly valuable in Asia due to } \\
\text { their unique physical features, including the color and shape of their leaves." (Garcia, 2019) } \\
\text { "Those plants had survived in their natural habitats for decades through rain and wind. That's what makes } \\
\text { them beautiful. You can't grow succulents like them with artificial measures." (Horowitz-Ghazi, 2018) }\end{array}$ \\
\hline $\begin{array}{l}\text { Social- } \\
\text { Reputational }\end{array}$ & $\begin{array}{l}\text { Motivated by the desire to give others } \\
\text { a certain impression, or to benefit } \\
\text { socially; or to gain currency in a } \\
\text { business transaction, or highlight } \\
\text { social standing or wealth. }\end{array}$ & $\begin{array}{l}\text { "Right now these plants are a boom in Korea, China and Japan. It's huge among domestic housewives. } \\
\text { It's a status thing," (McCormick, 2018). } \\
\text { "I think things like this can quickly become a symbol of the middle class for the generation } 30 \text { and under } \\
\text { [in China], it's important for them to show that they are the generation that got the privilege of buying } \\
\text { things." (McCormick, 2018) } \\
\text { "They want to have the plant that isn't native to where they are or the plant that people see via social } \\
\text { media. . In this situation, a plant has become so popular that the idea that someone does not have it } \\
\text { makes people go the extra mile." (Garcia, 2019) }\end{array}$ \\
\hline $\begin{array}{l}\text { Functional - } \\
\text { Medicinal }\end{array}$ & $\begin{array}{l}\text { Motivated by the desire to treat an } \\
\text { illness or promote wellness (i.e., } \\
\text { curative/preventative). }\end{array}$ & $\begin{array}{l}\text { Like cactus, Dudleya is a plant that contains water in its leaves and stems to live in a dry climate. It's also } \\
\text { in the limelight as an investment tool in South Korea for its air purifying effect and home decoration use. } \\
\text { (Three Koreans arrested, 2018) }\end{array}$ \\
\hline $\begin{array}{l}\text { Financial- Future } \\
\text { Profit }\end{array}$ & $\begin{array}{l}\text { Motivated by the desire for future } \\
\text { profit or an investment strategy. }\end{array}$ & $\begin{array}{l}\text { "In South Korea and China, Dudleya is traded for } \$ 40-50 \text { per head. Growing its seedlings and trading } \\
\text { them at high prices is used as an investment tool." (Han, 2018). }\end{array}$ \\
\hline $\begin{array}{l}\text { Spiritual-Spiritual } \\
\text { Well Being }\end{array}$ & $\begin{array}{l}\text { Motivated by the desire to improve } \\
\text { one's fortune in this life or any others. }\end{array}$ & $\begin{array}{l}\text { "The squat plants boast a geometric beauty reminiscent to some of the blossom of a lotus flower." (Lake } \\
\text { County News, 2018). }\end{array}$ \\
\hline
\end{tabular}

Functional-Medicinal (air purification); and Financial-Future Profit (investment tool). Motivations highlighted in other articles included speculation that within China and Korea in particular, there was pressure to acquire a $D$. farinosa in order to demonstrate economic security to others through the purchase of a non-essential popular item (Social-Reputational), in particular one that requires skills of caretaking (McCormick, 2018). Others suggested that $D$. farinosoa's shape was reminiscent of the shape of a lotus flower (Spiritual-Spiritual well-being), an auspicious spiritual and religious symbol in many East Asian cultures that is especially associated with Buddhism (Ward, 1952).

The diversity of explanations for consumer motivation for Dudleya farinosa presented in media articles mirror the diversity of beliefs and opinions expressed by CDFW staff as well as commercial succulent dealers and members of the California plant conservation community I interviewed. In part this is because many of the perspectives offered in media articles came from CDFW staff or noted succulent market and/or D. farinosa experts in California. Thus, there was a recirculation of themes between a relatively small group of identified key experts and the motivational narratives described in media articles.
A consistent consumer motivation narrative focused on the status of poached $D$. farinos $a$ as wild-origin plants (and thus seen as more rare or exotic), coupled with the rise of a growing mass consumer market in East Asia:

There are people who will place a higher value on anything that is difficult to attain. Let's take the recreational sturgeon fishery. Sturgeon are barely populous enough to sustain a recreational fishery. It's a very highly regulated fishery and because they are so difficult to attain, poachers want them more than ever so the value goes up. With Dudleya, the fact that they are difficult to attain and illegal to attain then people just want them more. (CDFW Interview, January 16, 2019).

There is a giant rising middle class in China and in South Korea, they have more disposable income, and want to beautify their houses, and this [Dudleya farinosa] has become the fad, to have these cute little plants in their house. And so... there's the rise of more people having disposable income. And I think, it's like wild versus farmed salmon, having the place that it is from, the natural thing, there's kind of like a, 'this came from this place.' (District Attorney's Office Interview, January 18, 2019).

While most interviewees expressed the speculative nature of these theories, there was nevertheless general consistency across 
media articles and interviewers about the primary motivations behind the rise of consumer demand for D. farinosa. As one media article put it, consumer motivation could be understood as stemming from a rapidly growing "fever" among "housewives" and "hipsters" (i.e., mass consumer market) for succulents in Korea and China in general (Lanyon, 2018), with wild-harvested D. farinosa plants possessing greater value and monetary worth due to their exotic provenance and having wild-origin characteristics (especially in color, form, and size) compared to cultivated plants. This framing of "housewives" and "hipsters" being the driving consumer market behind this trade was echoed by several other media articles, suggesting that the emergent trade in $D$. farinosa was the unfortunate result of the craze for other mass-market succulents in large sectors of the overall population (e.g., Horowitz-Ghazi, 2018; McCormick, 2018; Goodyear, 2019). In this context, "housewives" and "hipsters" are codes for particular consumer market sectors-namely, married women whose primary activities may be domestic responsibilities ("housewives"), and a growing market of plant enthusiasts within the 'millennial' and 'Gen-Z' generations ("hipsters").

\section{Contrasting Narratives of Motivations for Dudleya farinosa Demand}

The primary consumer motivations described by Korean succulent dealers and commercial operators were narrower in scope and also different than those described in popular press outlets, as was the characterization of who the primary consumers of $D$. farinosa were. In particular, Korean dealers emphasized that $D$. farinosa was not a widely popular succulent plant amongst mainstream consumers (i.e., "housewives" and "hipsters") and that it was specifically desired by specialized and typically more experienced collectors. Like many countries, succulents are currently immensely popular in South Korea, but interviewees made clear there is little relationship between the overall popularity of succulents and those desiring to possess D. farinosa. In addition to the consistency of this perspective across all succulent experts and purveyors of $D$. farinosa I interviewed in South Korea, after visiting three of the largest succulent plant markets in Seoul open to retail customers, I was only able to find one vendor selling any $D$. farinosa. This vendor said that they do not normally stock them due to lack of demand, though they can acquire them when requested (Succulent Vendor Interview, October 11, 2019). Other interviewed commercial market dealers affirmed that they did not normally stock $D$. farinosa because it was not widely desired by consumers, and its overall desirability is declining. Rather than finding D. farinosa at general household plant and succulent consumer markets, D. farinosa were primarily only available from a select number of specialist succulent growing operations, which are also the primary vendors selling D. farinosa online in South Korea for an international market.

Interviews with commercial succulent dealers and botanical experts in both California and South Korea confirmed that D. farinosa would be difficult to keep alive under the conditions available in most consumer homes or outside, where freezing temperatures would kill plants in winter. D. farinosa are easily killed or damaged by overwatering, and in the wild they grow on cliffsides; thus, experts suggested that growing them in vertical pots could result in root rot and eventual death if not carefully maintained. Succulent dealers in South Korea confirmed that D. farinosa is not a plant for beginner growers, but requires advanced levels of care and was predominantly sought out by specialist collectors who maintain large collections of plants, oftentimes renting space in professionally maintained greenhouses where they keep their collections and visit them (Succulent Greenhouse Operator and Vendor Interview, October 20, 2019).

Despite the frequent speculations expressed by CDFW officials, California conservationists, and succulent experts about Asian consumers valuing poached $D$. farinosa because of their wild origins, the growers I interviewed in South Korea who sold and/or possessed $D$. farinosa were nearly exclusively interested in their aesthetic qualities. Their status as 'wild origin' plants did not elevate their value nor desirability for most customers (Succulent Vendor and Collector Interview, October 13, 2019). While some interviewees had a general awareness of where they came from (California), price was determined by the size and quality of plant, as well as supply and demand. On the question of why D. farinosa were believed to be so desirous in East Asia, one dealer replied, "this isn't about Chinese collectors or Japanese collectors or Korean collectors, this is about individual collectors and what they want" (Succulent Vendor Interview, October 11 2019).

Although their origin as 'wild' plants did not matter to collectors, the age and size of $D$. farinosa plants did-larger plants were more valuable than smaller plants. But it is important to distinguish between large plants and 'wild' plants in how they accrue in value. In South Korea, most of the visibly wild origin plants I saw (identifiable by signs of pest damage, growth patterns, weathering, and size) were being maintained in commercial greenhouses and would not be put up for sale until they had grown sufficient new foliage and recovered from the stress of transport and their general environmental conditions in the wild to be seen as presentable show pieces, when they would fetch higher sale prices. The tell-tale signs of 'wildness' were seen by most dealers not as desirable qualities, but as imperfections which negatively affected their monetary worth (Succulent Online Vendor Interview, October 14, 2019). This difference is important, as it suggests both why $D$. farinosa poaching occurred-a limited supply of large plants in a growing East Asian as well as global market-as well as a simple solution to the problem by developing a sustainable trade in artificially cultivated plants abroad. I observed (and confirmed in interviews) that a number of specialized commercial growers in South Korea are now cultivating seed grown $D$. farinosa, but it takes time for these plants to develop into larger plants often sought by more passionate collectors. In fact, the reputation of South Korean succulent growers is so great that the demand for D. farinosa from China and other countries in the region is actually for D. farinosa (and other succulents) grown in Korea, rather than representing a demand for exotic, California-grown plants (Succulent Greenhouse Operator and Vendor Interview, October 13, 2019). 
In summary, the principal thrust of what drove people to poach Dudleya farinosa plants relates to a disjuncture between the temporality of plants and the capacity to meet demandD. farinosa grows slowly and, although desired by a specialist market, there was sufficient global demand to quickly deplete incountry cultivated supply. There was, several years ago, a surge in interest in D. farinosa in Korea, China, and Japan, among other places-including Europe-facilitated by social media platforms and the rapid dissemination in information as well as growth in desire for these plants amongst specialist collectors. Social media platforms and group messaging systems enable both the development of communities of interest and communication between group members, but also serve as platforms for both legal and illegal trade (Hinsley et al., 2016). In this way, there was not just Experiential-Recreational and ExperientialSensory motivations for East Asian succulent growers to acquire D. farinosa, but also Social-Relational motivations. As increasing numbers of people within succulent communities acquired D. farinosa, there was interest by collectors to share in the experience of growing them within their enthusiast in-person and online communities. Thomas-Walters et al. (2020a, p. 5) define Social-Relational motivation as being "Motivated by the desire for companionship; or for closeness to a larger social group or cultural/national identity." Through popular group messaging applications, Instagram, and Facebook groups, there was motivation to share experience with others through raising D. farinosa. This, combined with the experiential and sensory enjoyment the plants provide collectors, represented the primary consumer motivations for acquiring D. farinosa, which mirror the primary motivations behind succulent collection and growing as a hobby writ large.

From the perspective of succulent dealers as opposed to consumers, while $D$. farinosa is not currently listed on the appendices of CITES restricting their trade, phytosanitary certificates and plant importation permits into Korea were described by dealers as very cost prohibitive and simply "too expensive" (Succulent Greenhouse Operator and Vendor Interview, October 13, 2019; US Commercial Greenhouse Manager Interview, February, 18, 2019). Within Korea there was a demand for $D$. farinosa and no readily available supply, and the cost of importation only further increased the cost of obtaining plants. Ironically, one of the reasons there was a limited supply of commercially (and legally) available D. farinosa within the US is that according to interviewed succulent commercial growers in the US, there has been a declining interest in the species amongst US succulent consumers. As one Dudleya expert commented, "at a time when they were stealing them out of the wild we couldn't sell them at our plant stalls for five bucks" (Dudleya Expert Interview, January 22, 2019). This created a profitable opportunity for the rise of an illicit market for imported $D$. farinosa. The fact that $D$. farinosa plants are now being legally sold by Korean growers to Chinese and other international customers relates to the reputation of Korean growers for highquality plants. This suggests that efforts of artificial cultivation in South Korea should be able to successfully meet market demands in time, as it was not the provenance of their origin in California that made wild D. farinosa plants so desirable. At the time this research was conducted, all interviewed specialist retailers who sold $D$. farinosa said that prices for $D$. farinosa were dropping, and that many of the more spectacular plant prices seen online (and often referenced by CDFW officials when making estimates of their value) were only aspirational numbers to draw attention to the plants as stand-out specimens. This tactic was used both to start negotiating prices for prized plants with potential buyers, as well as to draw more general attention to a seller's overall collection (Succulent Greenhouse Operator and Vendor Interview, October 14, 2019).

Based on the collected and presented evidence in this paper, it appears likely that the ongoing illicit trade in wild harvested $D$. farinosa is likely to diminish as commercial Korean succulent operators develop an increasing stock of $D$. farinosa of a desirable size that many international customers seek out. Based on interviews and market visits, other succulents, especially South African lithops and conophytum, are growing in popularity in South Korea and East Asia, which may represent a new concern. Notably, a Korean man who fled the United States to avoid charges for illegal D. farinosa harvesting was recently apprehended in South Africa (and extradited to the United States) with over 60,000 conophytum plants, some of which were believed to be over 250-300 years old (Hyman, 2020). Coordinated efforts between Korean government agencies such as the Cactus and Succulent Research Institute at the Gyeonggido Agricultural Research and Extension Services (GARES), international partners, and commercial growers to pre-emptively breed desirable and threatened lithops and conophytum plants might help to reduce the likely possibility of further illegal extraction of these increasingly popular plants.

\section{CONCLUSION}

Comparisons of consumer motivations given by US-based law enforcement as well as botanical experts and Korean succulent experts reveal how reporting on the $D$. farinosa thefts: (a) were often either inaccurate or incomplete; (b) played upon blunt stereotypes about East Asian wildlife consumers valuing rare and exotic wild-origin material; and (c) led to a circulation of inaccurate narratives that were recycled within other groups and social networks internationally. Both law enforcement and popular media articles made a variety of assumptions about the drivers of this emergent illegal trade based on limited data or evidence. These assumptions were further fueled by unverified hypotheses driven in part by stereotypes about what motivates wildlife consumption in East Asia (Margulies et al., 2019a; Dang and Nielsen, 2020). In the case of Dudleya farinosa, assumptions focused on their perceived value as rare, exotic, and wild-collected species, with both news reports and some interviewees in the United States making mention of rhino horn or elephant ivory trades as meaningful comparisons. The contrast in understandings of consumer demand for D. farinosa between Korean succulent experts and US-based law enforcement and succulent experts is especially striking. This contrast suggests the need for the incorporation of more in-depth qualitative research in the early stages of understanding consumer motivations in 
relation to forms of IWT, as well as continued skepticism when racialized tropes about IWT consumer motivations emerge in the context of IWT in East Asia.

Understanding the complexities and motivations of parties engaged in the purchasing of illicitly traded wildlife products is essential for informing effective, socially just and responsible interventions to effectively curtail IWT and promote sustainable wildlife trades (Wyatt, 2009; Duffy et al., 2016; Doughty et al., 2019; Thomas-Walters et al., 2020b). Echoing the sentiments of others, research into the underpinnings of the illicit trade in $D$. farinosa speaks to the greater need for deeper interdisciplinary conversation and engagement between criminologists, conservation scientists, geographers and anthropologists in IWT-related research in order to inform more sustainable plant trades (Blair et al., 2017; Boratto and Gibbs, 2019; Gore et al., 2019). Close attention to foundational drivers of illicit trades and consumer motivations are essential in order to develop holistic understandings of why trades exist and how they might be responded to in the form of mediating consumer behavior. As demonstrated by this study, qualitative research has an important role to play in understanding fundamental drivers of illegal trades in wildlife, a necessary step toward designing effective species conservation interventions and the promotion of sustainable trades.

\section{DATA AVAILABILITY STATEMENT}

The datasets presented in this article are not readily available because they represent interview transcripts that are not permitted to be shared with outside parties under the IRB/ethics approvals of this research. Requests to access the datasets should be directed to jdmargulies@ua.edu.

\section{ETHICS STATEMENT}

This study was reviewed and approved by the University of Sheffield and the University of Alabama under two different ethics protocols. From December 2017 to August 2019, this research was conducted under the ethical approval \#016909 from

\section{REFERENCES}

Altheide, D. L., and Schneider, C. J. (2012). Qualitative Media Analysis, Vol. 38. Thousand Oaks, CA: Sage Publications.

Ballvé, T. (2020). Investigative ethnography: a spatial approach to economies of violence. Geogr. Rev. 110, 238-251. doi: 10.1111/gere.12347

Blair, M. E., Le, M. D., Sethi, G., Thach, H. M., Nguyen, V. T., Amato, G., et al. (2017). The importance of an interdisciplinary research approach to inform wildlife trade management in Southeast Asia. BioScience 67, 995-1003. doi: 10.1093/biosci/bix113

Boratto, R., and Gibbs, C. (2019). Advancing interdisciplinary research on illegal wildlife trade using a conservation criminology framework. Eur. J. Crimino. 1477370819887512. doi: 10.1177/1477370819887512

California Natural Diversity Database [CNDDB] (2020). State and Federally Listed Endangered, Threatened, and Rare Plants of California. Sacramento, CA: California Department of Fish and Wildlife. the Department of Politics at the University of Sheffield, which is the appropriate authority to carry out reviews for the University Research Ethics Committee. It also underwent additional review by the European Research Council. From October 2019, this research was conducted under the IRB approvals of the University of Alabama \#19-10-2891. Participants in the study provided either written or oral informed consent based on their preference before participating in this study, in accordance with appropriate national legislation and institutional requirements.

\section{AUTHOR CONTRIBUTIONS}

JM was responsible for the conceptualization, research, analysis, and writing of the manuscript.

\section{FUNDING}

This work was supported by the European Research Council Grant \# 694995 (BIOSEC), as well as funding from the College of Arts and Sciences, University of Alabama.

\section{ACKNOWLEDGMENTS}

I owe my deepest gratitude and thanks to Dr. Jinah Kwon and Jaehyun Kim for their phenomenal and dedicated research assistance on the Dudleya trade in South Korea in 2019. Further Korean translation assistance was graciously provided by Heeyoung Kang. I wish to thank the two reviewers of this article and editor TL who provided helpful feedback and suggestions on a previous iteration of this article, and I am especially grateful to them for their very timely reviews. This article benefited from helpful feedback and comments during a presentation at the Third Annual State of Biodiversity Conference at the San Diego Natural History Museum in February, 2020. Lastly, I would like to thank the BIOSEC research community in the Department of Politics and International Relations at the University of Sheffield for their constant enthusiasm and collective support. Any mistakes and errors remain my own.

Convention on International Trade in Endangered Species of Wild Fauna and Flora (2013). Consideration of Proposals for Amendment of Appendices I AND II. CoP 16 Prop 57. 1-10. Available online at: https://cites.org/sites/default/files/eng/ cop/16/prop/E-CoP16-Prop-57.pdf

Dang Vu, H. N., Nielsen, M. R., and Jacobsen, J. B. (2020). Reference group influences and campaign exposure effects on rhino horn demand: qualitative insights from Vietnam. People Nature doi: 10.1002/pan3.10121 [Epub ahead of print].

Dang, N. V. H., and Nielsen, M. R. (2020). Evidence or delusion: a critique of contemporary rhino horn demand reduction strategies. Hum. Dimens. of Wildlife doi: 10.1080/10871209.2020.1818896 [Epub ahead of print].

de Boer, H. J., Ghorbani, A., Manzanilla, V., Raclariu, A. C., Kreziou, A., Ounjai, S., et al. (2017). DNA metabarcoding of orchid-derived products reveals widespread illegal orchid trade. Proc. R. Soc. B Biol. Sci. 284:20171182. doi: $10.1098 / \mathrm{rspb} .2017 .1182$ 
Doughty, H., Veríssimo, D., Tan, R. C. Q., Lee, J. S. H., Carrasco, L. R., Oliver, K., et al. (2019). Saiga horn user characteristics, motivations, and purchasing behaviour in Singapore. PLoS One 14:e0222038. doi: 10.1371/journal.pone. 0222038

Duffy, R., St John, F. A., Büscher, B., and Brockington, D. (2016). Toward a new understanding of the links between poverty and illegal wildlife hunting. Conserv. Biol. 30, 14-22. doi: 10.1111/cobi.12622

Fram, S. M. (2013). The constant comparative analysis method outside of grounded theory. Q. Rep. 18, 1 .

Fukushima, C. S., Mammola, S., and Cardoso, P. (2020). Global wildlife trade permeates the Tree of Life. Biol. Conserv. 247:108503. doi: 10.1016/j.biocon. 2020.108503

Garcia, S. (2019). Poachers Stockpile 'Tiny and Cute' Succulents Worth $\$ 600,000$, Investigators Say. New York, NY: The New York Times.

Glaser, B. G. (1965). The constant comparative method of qualitative analysis. Soc.Probl. 12, 436-445. doi: 10.2307/798843

Goettsch, B., Hilton-Taylor, C., Cruz-Piñón, G., Duffy, J. P., Frances, A., Hernández, H. M., et al. (2015). High proportion of cactus species threatened with extinction. Nat. plants 1:15142. doi: 10.1038/nplants.2015.142

Goodyear, D. (2019). Succulent-Smugglers Descend on California. New York, NY: The New Yorker. Available online at: https://www.newyorker.com/news/ california-chronicles/succulent-smugglers-descend-on-california

Gore, M. L., Braszak, P., Brown, J., Cassey, P., Duffy, R., Fisher, J., et al. (2019). Transnational environmental crime threatens sustainable development. Nat. Sust. 2, 784-786. doi: 10.1038/s41893-019-0363-6

Han, J. (2018). Three Koreans Arrested by LA Police Last Week. Seoul: Seoul Shinmun.

Hinsley, A., Lee, T. E., Harrison, J. R., and Roberts, D. L. (2016). Estimating the extent and structure of trade in horticultural orchids via social media. Conserv. Biol. 30, 1038-1047. doi: 10.1111/cobi.12721

Hinsley, A., Nuno, A., Ridout, M., John, F. A. S., and Roberts, D. L. (2017). Estimating the extent of CITES noncompliance among traders and endconsumers; lessons from the global orchid trade. Conserv. Lett. 10, 602-609. doi: $10.1111 /$ conl.12316

Hinsley, A., and 't Sas-Rolfes, M. (2020). Wild assumptions? Questioning simplistic narratives about consumer preferences for wildlife products. People Nat. doi: 10.1002/pan3.10099 [Epub ahead of print].

Horowitz-Ghazi, A. (2018). The Case of the Stolen Succulents. All Things Considered: National Public Radio. Available online at: https://www.npr.org/ 2018/05/20/611570479/the-case- of-the-stolen-succulents

Hübschle, A. M. (2017). The social economy of rhino poaching: of economic freedom fighters, professional hunters and marginalized local people. Curr. Sociol. 65, 427-447. doi: 10.1177/0011392116673210

Hyman, A. (2020). Koreans Fined R5m as Poachers Target SA's Succulent Treasure Chest. London: Sunday Times.

Investigaciones Zeta (2018). Crece Mercado Negro de la "Sempreviva". Tijuana: Zeta. Available online at: https://zetatijuana.com/2018/07/crece-mercadonegro-de-la-siempreviva/

Lake County News (2018). Two Men Sentenced for Felony Succulent Theft in Mendocino Coast Case. Clear Lake, CA: Lake County News.

Lanyon, C. (2018). California's Succulent Smugglers: Plant Poachers Seed Asia's Desire for Dudleya. Hong Kong: South China Morning Post Magazine.

Lavorgna, A., Rutherford, C., Vaglica, V., Smith, M. J., and Sajeva, M. (2018). CITES, wild plants, and opportunities for crime. Eur. J. Criminal Policy Res. 24, 269-288. doi: 10.1007/s10610-017-9354-1

Lavorgna, A., and Sajeva, M. (2020). Studying illegal online trades in plants: market characteristics, organisational and behavioural aspects, and policing challenges. Eur. J. Criminal Policy Res. doi: 10.1007/s10610-020-09447-2 [Epub ahead of print].

Margulies, J. D., Bullough, L. A., Hinsley, A., Ingram, D. J., Cowell, C., Goettsch, B., et al. (2019a). Illegal wildlife trade and the persistence of "plant blindness". Plants People Planet 1, 173-182. doi: 10.1002/ppp3.10053

Margulies, J. D., Wong, R. W., and Duffy, R. (2019b). The imaginary 'Asian Super Consumer': a critique of demand reduction campaigns for the illegal wildlife trade. Geoforum 107, 216-219. doi: 10.1016/j.geoforum.2019. 10.005

McCormick, E. (2018). Stolen Succulents: California Hipster Plants at Center of Smuggling Crisis. The Guardian, US Edition. Available online at: https://www.theguardian.com/environment/2018/apr/27/stolen-succulentscalifornia-hipster-plants-at-center-of-smuggling-crisis

Thomas-Walters, L., Hinsley, A., Bergin, D., Doughty, H., Eppel, S., MacFarlane, D., et al. (2020a). Motivations for the use and consumption of wildlife products. Conserv. Biol. doi: 10.1111/cobi.13578 [Epub ahead of print].

Thomas-Walters, L., Veríssimo, D., Gadsby, E., Roberts, D., and Smith, R. J. (2020b). Taking a more nuanced look at behavior change for demand reduction in the illegal wildlife trade. Conserv. Sci. Pract. 2:e248. doi: 10.1111/csp2.248

Massé, F., Dickinson, H., Margulies, J., Joanny, L., Lappe-Osthege, T., and Duffy, R. (2020). Conservation and crime convergence? Situating the 2018 London Illegal Wildlife Trade Conference. J. Polit. Ecol. 27, 23-42. doi: 10.2458/v27i1. 23543

Massé, F., and Margulies, J. D. (2020). The geopolitical ecology of conservation: the emergence of illegal wildlife trade as national security interest and the re-shaping of US foreign conservation assistance. World Dev. 132:104958. doi: 10.1016/j.worlddev.2020.104958

Maxwell, J. A. (2012). Qualitative Research Design: An Interactive Approach, Vol. 41. Thousand Oaks, CA: Sage publications.

McCabe, S. W. (2012). "Dudleya farinosa," in Jepson Flora Project, ed. Jepson eFlora. Avaliable at: /eflora/eflora_display.php?tid=23655 (accessed on June 30, 2020).

Phelps, J., and Webb, E. L. (2015). "Invisible" wildlife trades: southeast Asia's undocumented illegal trade in wild ornamental plants. Biol. Conserv. 186, 296-305. doi: 10.1016/j.biocon.2015.03.030

Sajeva, M., Carimi, F., and McGough, N. (2007). The convention on international trade in endangered species of wild Fauna and Flora (CITES) and its role in conservation. Funct. Ecosys. Commun. 1, 80-85.

Three Koreans arrested (2018). Three Koreans Arrested for Unauthorized Harvesting of wild Succulents in the US. Seoul: Herald Economy.

Ward, W. E. (1952). The lotus symbol: its meaning in Buddhist art and philosophy. J. Aesthet. Art Criticism 11, 135-146. doi: 10.2307/426039

Wong, R. W. Y. (2019). The Illegal Wildlife Trade in China: Understanding the Distribution Networks. Palgrave Macmillan.

Wyatt, T. (2009). Exploring the organization of Russia Far East's illegal wildlife trade: two case studies of the illegal fur and illegal falcon trades. Glob. Crime 10, 144-154. doi: 10.1080/17440570902783947

Wyatt, T. (2013). Wildlife Trafficking: A Deconstruction of the Crime, the Victims and the Offenders. Basingstoke: Palgrave Macmillan. doi: 10.1057/ 9781137269249

Wyatt, T., van Uhm, D., and Nurse, A. (2020). Differentiating criminal networks in the illegal wildlife trade: organized, corporate and disorganized crime. Trends Organ. Crime doi: 10.1007/s12117-020-09385-9 [Epub ahead of print].

Zhu, A., and Zhu, G. (2020). Understanding China's wildlife markets: trade and tradition in an age of pandemic. World Dev. 136:105108. doi: 10.1016/j. worlddev.2020.105108

Zhu, A. L. (2020). China's rosewood boom: a cultural fix to capital overaccumulation. Ann. Am. Assoc. Geogr. 110, 277-296. doi: $10.1080 / 24694452.2019 .1613955$

Conflict of Interest: The author declares that the research was conducted in the absence of any commercial or financial relationships that could be construed as a potential conflict of interest.

Copyright (C) 2020 Margulies. This is an open-access article distributed under the terms of the Creative Commons Attribution License (CC BY). The use, distribution or reproduction in other forums is permitted, provided the original author(s) and the copyright owner(s) are credited and that the original publication in this journal is cited, in accordance with accepted academic practice. No use, distribution or reproduction is permitted which does not comply with these terms. 